\title{
Expertos del retablo europeo se reúnen en la abadía francesa de l'Epau
}

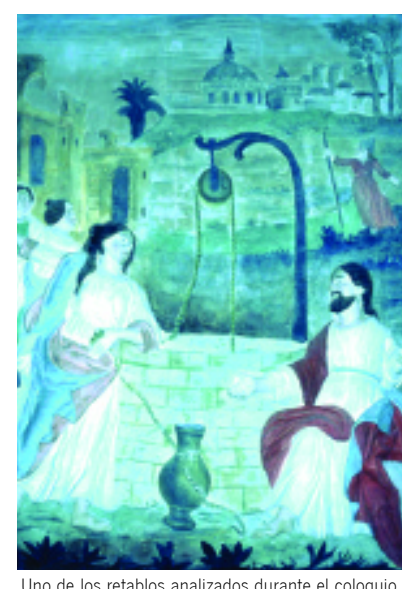

Uno de los retablos analizados durante el coloquio
Del 13 al 16 de octubre de 2004, la Asociación Rencontre avec le Patrimoine Religieux de la Región Centro francesa celebró el coloquio La Europa de los Retablos en la Abadía de l'Epau (Le Mans).

Después de una introducción sobre la significación de las imágenes y su lenguaje -histórico, artístico, espiritual- hubo unas veinticuatro comunicaciones que presentaron los trabajos que condujeron a los congresistas desde Bélgica y Países Bajos a España -la Seo de Zaragoza, la Capilla Mayor de Granada-, pasando por Italia, Polonia y Francia.

Los temas de las comunicaciones fueron variados, como lo manifiestan los ejemplos siguientes, lista no exhaustiva:

$>$ retablos esculpidos en Países Bajos

$>$ retablos italianos de las colecciones de los Reyes de Francia y su influencia en la producción francesa > la columna salomónica: modelos y su utilización en los retablos franceses e italianos

$>$ el retablo y el altar ¿alianza o rivalidad?

$>$ retablos barrocos en Varsovia en el siglo XVIII

$>$ terracota: los escultores del Maine o el nacimiento de un centro artístico regional hacia 1600

El coloquio forma parte de las acciones anuales que realiza la Asociación Rencontre avec le Patrimoine Religieux, fundada en 1992 para responder a una necesidad de formación e información. Rencontre avec le Patrimoine Religieux publica los Cahiers d'Art Sacré, generalmente dos veces al año. El próximo Cahier incluirá las comunicaciones del coloquio La Europa de los Retablos.

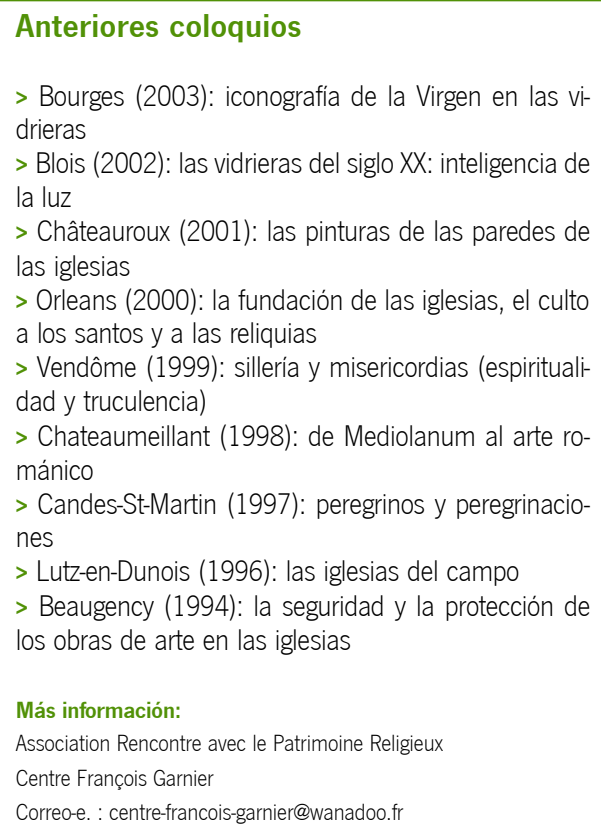

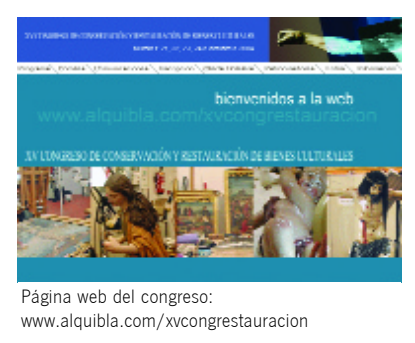

El XV Congreso de Conservación y Restauración de Bienes Culturales, celebrado entre el 21 y 24 de octubre de 2004 en Murcia, contó con la presencia de profesionales de reconocido prestigio internacional en el campo de la restauración y el análisis científico de obras de arte, tanto por parte de los ponentes invitados, como por los asistentes, con aportaciones de comunicaciones distribuidas en 11 grupos de trabajo. Ha destacado la cada vez mayor participación de profesionales en el grupo de Nuevas Tecnologías y de Intervención en el Patrimonio Arquitectónico.

Como conclusión general del Congreso se puede extraer que, siendo último beneficiario el Patrimonio Cultural, los profesionales dedicados tanto a la docencia como a la investigación y desarrollo tecnológico dentro de este campo deben man- tener una postura unificada, sobre todo en estos momentos en que se camina conjuntamente hacia la construcción del Espacio Europeo de la Educación Superior y la Investigación. Será posible con ello conseguir, finalmente, la unificación de titulaciones existentes en la actualidad y eliminar diferencias e intrusismo.

Más información:

Centro de Restauración

Dirección General de Cultura de la Región de Murcia

Web: www.alquibla.com/xvcongrestauracion

Pilar Roig

Catedrática de Restauración de la

Universidad Politécnica de Valencia 